\title{
Perkinsus sp. infecting the oyster Crassostrea rhizophorae from estuaries of the septentrional Northeast, Brazil
}

\author{
M. P. Dantas-Neto ${ }^{a *}$, R. C. Sabry ${ }^{b}$, L. P. Ferreira ${ }^{a}$, L. S. Romão and R. Maggioni ${ }^{a}$ \\ anstituto de Ciências do Mar - LABOMAR, Universidade Federal do Ceará - UFC, \\ Av. da Abolição, 3507, Meireles, CEP 60165-081, Fortaleza, CE, Brazil \\ 'Instituto Federal de Educação Ciência e Tecnologia - IFCE, Campus Aracati, \\ Rua Teófilo Pinto, 200, Farias Brito, CEP 62000-800, Aracati, CE, Brazil \\ *e-mail: maxfloyd@hotmail.com
}

Received: April 10, 2014 - Accepted: July 9, 2014 - Distributed: November 30, 2015

(With 2 figures)

\begin{abstract}
The mangrove oyster Crassostrea rhizophorae is an estuarine resource exploited by riverside communities in Northeast Brazil. Despite its socioeconomic importance, studies on the health status of this bivalve are scanty in this region. The purpose of the present study was to investigate the presence of the protozoan Perkinsus sp. in C. rhizophorae collected in August and September 2011 in three estuaries of the septentrional Northeast, Brazil: Jaguaribe (Ceará), Camurupim (Piauí) and Carnaubeiras (Maranhão) (n=150 specimens/site). The samples were submitted to Ray's fluid thioglycollate medium (RFTM), PCR and histology assays. The RFTM assay revealed spherical, blue or bluish-black hypnospores of the genus Perkinsus in 50 specimens (Jaguaribe $=17.3 \%$, Camurupim $=5.3 \%$, Carnaubeiras $=10.6 \%$ ). The intensity of the infection ranged from very light (1-10 cells per slide) to severe (more than 40 cells in each of 10 fields of the slide) for Jaguaribe; very light for Camurupim and very light to moderate (at least 40 cells observed in each of 10 fields of the slide) for Carnaubeiras. When submitted to confirmatory PCR analysis, 6 cases were confirmed (Jaguaribe=3, Camurupim=1, Carnaubeiras=2). The histology confirmed 21 cases of infection in specimens from the three estuaries. Although local collectors have reported no mortality in oyster populations that might be attributed to infection by Perkinsus, health surveillance of oyster populations in the septentrional region of Northeast Brazil is advisable.
\end{abstract}

Keywords: Perkinsus, Crassostrea rhizophorae, RFTM, PCR.

\section{Perkinsus sp. infectando a ostra Crassostrea rhizophorae de estuários do Nordeste setentrional, Brasil}

\begin{abstract}
Resumo
A ostra-do-mangue Crassostrea rhizophorae é um recurso estuarino explorado por comunidades ribeirinhas do Nordeste do Brasil. Apesar de sua importância socioeconômica, estudos sobre o estado de saúde deste bivalve são escassos na região. O objetivo deste estudo foi investigar a presença do protozoário Perkinsus sp. em C. rhizophorae coletada em agosto e setembro de 2011, em três estuários da região setentrional do Nordeste brasileiro: Jaguaribe (Ceará), Camurupim (Piauí) e Carnaubeiras (Maranhão) ( $n=150$ espécimes/local). As amostras foram submetidas ao meio líquido de tioglicolato de Ray (RFTM), PCR e ensaios histológicos. A análise em RFTM revelou hipnósporos esféricos azuis ou preto-azulados do gênero Perkinsus em 50 espécimes (Jaguaribe $=17,3 \%$, Camurupim= 5,3\%, Carnaubeiras $=10,6 \%$ ). A intensidade de infecção variou de muito leve (1-10 células por lâmina) a severa (mais de 40 células em cada um dos 10 campos da lâmina) para o Rio Jaguaribe; muito leve para o Rio Camurupim e muito leve a moderada (pelo menos 40 células observadas, em cada um dos 10 campos da lâmina) para o Rio Carnaubeiras. Quando submetidos à análise confirmatória por PCR, foram confirmados 6 casos (Jaguaribe=3, Camurupim=1, Carnaubeiras=2). A histologia confirmou 21 casos de infecção em espécimes dos três estuários. Embora os coletores locais não tenham relatado nenhuma mortalidade em populações de ostras que pudesse ser atribuída à infecção por Perkinsus, é aconselhável um monitoramento sobre o estado de saúde de populações de ostras da região.
\end{abstract}

Palavras-chave: Perkinsus, Crassostrea rhizophorae, RFTM, PCR. 


\section{Introduction}

The protozoan Perkinsus sp. belongs to a group of parasitic protozoa which infect mollusks worldwide, particularly bivalves. Since the first report of Perkinsus marinus infecting the American oyster Crassostrea virginica (Gmelin, 1791) in the Gulf of Mexico (Mackin et al., 1950), other species of the genus Perkinsus have been reported infecting several species of marine mollusks around the world (Lester and Davis, 1981; Azevedo, 1989; Blackbourn et al., 1998; Villalba et al., 2004; Choi and Park, 2010). In Brazil, Sabry et al. (2009) recorded the first occurrence of Perkinsus sp. infecting natural populations of the oyster Crassostrea rhizophorae (Guilding, 1828) in the Pacoti river estuary (Ceará, Northeast Brazil).

According to the Office International des Epizooties (OIE), two species of the phylum Perkinsozoa, Perkinsus marinus and Perkinsus olseni, are notifiable (OIE, 2012) due to the substantial mortality rates and economic losses with which they are associated around the world (Villalba et al., 2004; Choi and Park, 2010). Thus, P. marinus was responsible for substantial losses in populations of the American oyster $C$. virginica along the U.S. Atlantic coast and the Gulf of Mexico (Burreson and Calvo, 1996), while $P$. olseni is known to have decimated populations of the abalone Haliotis rubra in Australia (Lester and Davis, 1981) and of the clam Ruditapes decussatus in Portugal (Azevedo, 1989).

Traditionally, infections by Perkinsus are diagnosed with Ray's fluid thioglycollate medium (RFTM). However, the technique does not discriminate between different species of Perkinsus and can lead to the misidentification of Perkinsus spp. and some dinoflagellate species (Almeida et al., 1999). Polymerase Chain Reaction (PCR) has been used routinely to aid in the confirmation and description of different species of Perkinsus infecting mollusks (Penna et al., 2001). For instance, PCR was used to identify P. olseni infecting $R$. decussatus on the coast of Spain and in the Mediterranean Sea (Elandaloussi et al., 2009) and Tridacna crocea in Vietnam (Sheppard and Phillips, 2008). Molecular studies have recognized seven species of the genus Perkinsus: P. marinus, $P$. olseni (=P. atlanticus), P. mediterraneus, P. qugwadi, P. honshuensis, P. beihaiensis and P. chesapeaki (=P. andrewsi) (Burreson et al., 2005).

Considering the socio-economic importance of C. rhizophorae to riverside populations along estuaries in Northeast Brazil, the purpose of this study was to evaluate wild populations of Crassostrea rhizophorae with regard to the presence of pathogens of the genus Perkinsus using the RFTM, histology and PCR techniques. The study complements reports published by Sabry et al. (2009), Silva et al. (2013) and Brandão et al. (2013) on the occurrence of this pathogen in the states of Ceará, Paraíba and Bahia, respectively. In addition, the study makes a significant contribution to current knowledge about the distribution of Perkinsus along the Brazilian coast and provides subsidies for the development of sanitary measures to prevent contamination of protozoan-free areas.

\section{Material and Methods}

\subsection{Sampling of oysters}

In August and September 2011, 450 specimens of Crassostrea rhizophorae were collected from the roots of the red mangrove (Rhizophora mangle) of three estuaries in Northeast Brazil: the Jaguaribe river (04² $27^{\prime} 39,21^{\prime \prime} \mathrm{S}$, $37^{\circ} 47^{\prime} 31,68^{\prime}$ 'W) in Ceará ( $\left.\mathrm{n}=150\right)$, the Camurupim river (02 54' 51' S, $041^{\circ} 24^{\prime}$ 58,2" W) in Piauí (n=150), and the Carnaubeiras river ( $02^{\circ} 50^{\prime} 0,08^{\prime}$ ' S, $041^{\circ} 57^{\prime} 36,5$ ' W) in Maranhão $(n=150)$. The shell height of the oysters was measured in its major axis.

The tissues of each specimen were incubated in RFTM, while the gills were fixed in $95 \%$ alcohol for confirmatory PCR analysis. Thirty specimens in each collect of 150 oysters were submitted to histological assays.

Using a thermometer and a refractometer, the temperature and salinity of the water were measured at the time of sampling for the Jaguaribe river $\left(30^{\circ} \mathrm{C} ; 30 \%\right.$ ), the Camurupim river $\left(27^{\circ} \mathrm{C} ; 45 \%\right.$ ) and the Carnaubeiras river $\left(30^{\circ} \mathrm{C} ; 18 \%\right.$ o). The average shell height of the oysters from Jaguaribe, Cumurupim and Carnaubeiras estuaries was $58 \pm 8.4 \mathrm{~mm}, 50 \pm 5.4 \mathrm{~mm}$ and $50 \pm 5.2 \mathrm{~mm}$, respectively.

\subsection{Incubation of tissues in RFTM}

Two gill lamellae and the rectum of each specimen were incubated in RFTM (Ray, 1966) in the dark for 7 days at room temperature. Subsequently, the tissues were macerated on a slide and stained with a 3\% Lugol solution. The preparation was observed under an optical microscope for the presence of spherical, blue or bluish-black hypnospores of the genus Perkinsus.

The prevalence of infection by Perkinsus was defined as the total number of infected animals divided by the total number of oysters collected in each estuary (Bush et al., 1997). The intensity of the infection was estimated according to the Mackin scale (Ray, 1954).

\subsection{Detection of Perkinsus by polymerase chain reaction $(P C R)$}

Tissues testing positive for Perkinsus in the RFTM assay were preserved in 95\% alcohol for PCR analysis. DNA extraction was achieved with a DNAzol ${ }^{\circledR}$ kit (Invitrogen) following the manufacturer's directions, while PCR was performed with the primer set Perk ITS $85 / 750$ (Casas et al., 2002) which specifically hybridizes with conserved regions of the internal transcribed spacers (ITS) from the rRNA gene complex, unique to members of the genus Perkinsus (except for Perkinsus qugwadi incertae sedis). DNA extracted from cells of Perkinsus beihaiensis was used as positive control. In the negative control, the DNA was replaced by nuclease-free water.

Each $25 \mu \mathrm{L}$ reaction contained 50-100ng DNA template, 1x proprietary PCR buffer, $1.5 \mathrm{mM} \mathrm{MgCl} 2,0.2 \mathrm{mM}$ of each dNTP, $0.8 \mathrm{mM}$ of each primer, and 1 unit of Taq DNA polymerase (Invitrogen). The protocol included DNA denaturation at $94{ }^{\circ} \mathrm{C}$ for $10 \mathrm{~min}$ and 35 cycles of amplification at $94{ }^{\circ} \mathrm{C}(1 \mathrm{~min}), 55^{\circ} \mathrm{C}(1 \mathrm{~min})$ and $72{ }^{\circ} \mathrm{C}$ (1 min), followed by a final extension at $72^{\circ} \mathrm{C}$ for $10 \mathrm{~min}$. 

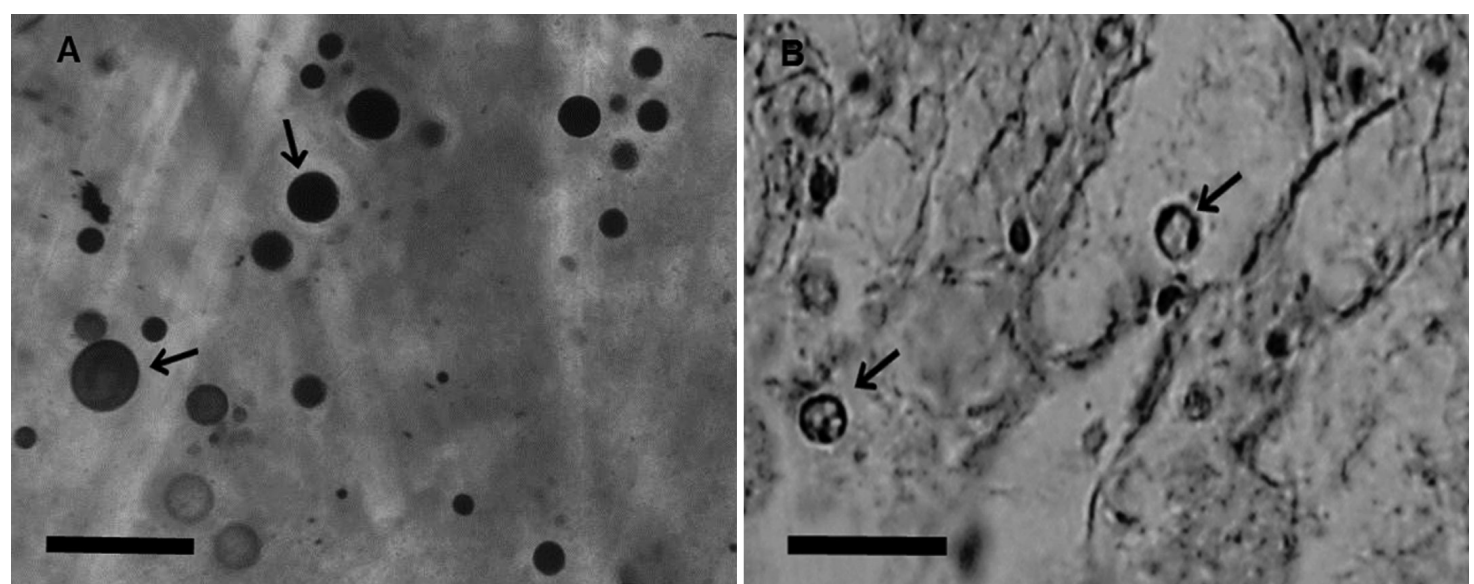

Figure 1. Histological sections showing cells of Perkinsus infecting the oyster Crassostrea rhizophorae. (A) Perkinsus sp. hypnospores in gill tissues of C. rhizophorae after incubation in RFTM and stained with Lugol's iodine solution. Scale bar $=50 \mu \mathrm{m}$. (B) Trophozoite of Perkinsus sp. (arrow) in connective tissue near the digestive gland. Scale bar $=20 \mu \mathrm{m}$.

The PCR products were separated by electrophoresis on $1.5 \%$ standard TAE agarose gel containing ethidium bromide.

\subsection{Histological sections}

The gills, gonads and digestive gland of 30 specimens from each collect of oysters $(n=150)$ were excised and fixed in Davidson's solution (Shaw and Battle, 1957) for 24 hours. Following embedding in histological paraffin at $60{ }^{\circ} \mathrm{C}, 5 \mu \mathrm{m}$ sections were prepared and stained with Harris' hematoxylin and eosin (H \&E) (Howard et al., 2004) and analyzed under an optical microscope. The observed prevalence of Perkinsus was defined as the number of infected specimens divided by the total number of analyzed oysters (Bush et al., 1997).

\section{Results}

\subsection{Detection of Perkinsus sp. by RFTM assay}

Fifty oysters from the three collects tested positive for perkinsiosis in RFTM (50/450). The enlarged, spherical cells of the pathogen $(5-55 \mu \mathrm{m}$ in diameter) stained black in Lugol (Figure 1A). The prevalence of infected oysters was 17.3\% (Jaguaribe), 5.3\% (Camurupim) and 10.6\% (Carnaubeiras) (Table 1). The intensity of the infection was very light to severe (Jaguaribe), very light (Camurupim) and very light to moderate (Carnaubeiras).

\subsection{Detection of Perkinsus sp. by PCR}

The 50 specimens testing positive for Perkinsus sp. in the RFTM assay were submitted to confirmatory PCR analysis. Six cases were confirmed (Jaguaribe $n=3$, Camurupim n=1, Carnaubeiras n=2) (Table 1 and Figure 2). The primer pair PerkITS produced amplicons of expected size ( $850 \mathrm{bp}$ ) in all the samples, confirming the presence of Perkinsus sp. (Figure 2).

\subsection{Histopathological analyzes}

The histological analysis confirmed 21 cases of the 50 cases detected by RFTM (Table 1). Trophozoites of Perkinsus were detected in the gills and connective tissues

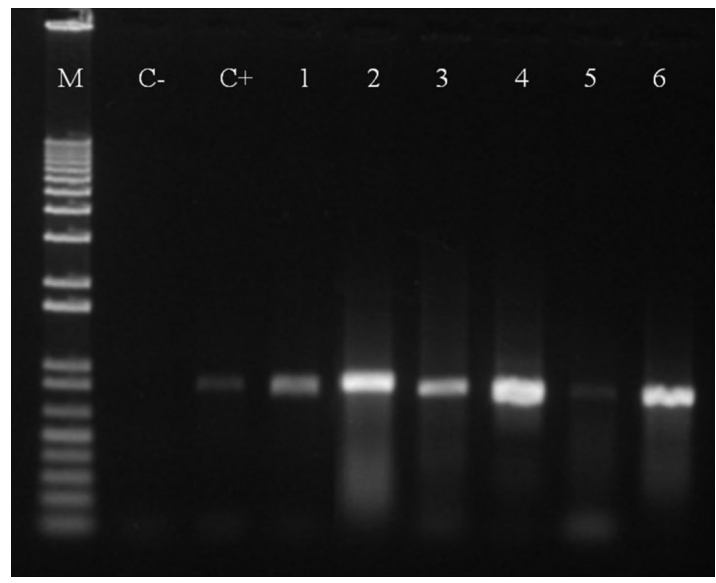

Figure 2. Molecular diagnosis of Perkinsus sp. in 1.5\% agarose gel. Detection of the rDNA ITS region of Perkinsus sp. by PCR. M: molecular marker (1 Kb Plus, Invitrogen), $\mathrm{C}$-: negative control (ultra-pure water): $\mathrm{C}+$ : positive control; lanes 1 (CE), 2 (CE), 3 (PI) 4 (MA), 5 (PI) and 6 (CE): positive samples.

Table 1. Prevalence (\%) of infection by Perkinsus sp. in 450 specimens of the oyster Crassostrea rhizophorae collected in three estuaries in Northeastern Brazil: Jaguaribe (Ceará), Camurupim (Piauí) and Carnaubeiras (Maranhão). The number of Perkinsus-positive oyster per sample is shown in parenthesis for each diagnostic technique.

\begin{tabular}{cccc}
\hline Estuary & RFTM (\%) & $\begin{array}{c}\text { Histology } \\
(\%)\end{array}$ & $\begin{array}{c}\text { PCR } \\
(\%)\end{array}$ \\
\hline Jaguaribe & $17.3(26 / 150)$ & $33.3(10 / 30)$ & $11.5(3 / 26)$ \\
Camurupim & $5.3(8 / 150)$ & $20(6 / 30)$ & $25.0(2 / 8)$ \\
Carnaubeiras & $10.6(16 / 150)$ & $16.6(5 / 30)$ & $6.2(1 / 16)$ \\
\hline
\end{tabular}

around the digestive gland of the oysters. The trophozoites were spherical, with a vacuole occupying most of the cytoplasm (Figure 1B). No damage or hemocyte infiltration was detected in the tissues infected by the pathogen. 


\section{Discussion}

In this study we report the occurrence of the protozoan Perkinsus sp. infecting the oyster Crassostrea rhizophorae in three estuaries of the states Ceará, Piauí and Maranhão, Northeast Brazil. Perkinsus sp. was detected by RFTM assay, a sensitive and reliable diagnostic technique, and subsequently submitted to confirmatory molecular diagnostics and histology.

The average prevalence of Perkinsus sp. infecting the oysters collected for this study was relatively low (up to $17.3 \%$ by RFTM). This is consistent with the absence of records of mortality among these oyster populations which might be associated with the parasite. However, the values found were higher than the prevalence of $6.7 \%$ recorded by Sabry et al. (2009) in oysters from Pacoti river, another estuary in Ceará. On the other hand, despite this difference, Brandão et al. (2013) reported a mean prevalence of $63 \%$ for Perkinsus sp. in C. rhizophorae populations from Bahia and Silva et al. (2013) prevalence of 92\% for Perkinsus sp. and up to $100 \%$ for Perkinsus marinus in the same species from Paraíba, two other states in Northeast Brazil.

Only 6 of the 50 cases detected by RFTM assays were confirmed by PCR, probably because most infections were very light and/or because the amount of gill tissue retrieved from each specimen for DNA extraction was too small to ensure the detection of the pathogen. In a discussion on the occurrence of false-negative PCR results in the detection of parasites in bivalves, Burreson (2008) reached the same conclusion. Other authors have reported discrepancies between RFTM and PCR results (Reece et al., 2008; Sabry et al., 2009), and other causes of sampling errors can compromising the accuracy of PCR assays, including the effects of focal or localized lesions (Burreson, 2008). Histological sections of oyster tissues contained cells of Perkinsus sp. with a vacuole occupying most of the internal volume of the cytoplasm, an eccentric nucleus and prominent nucleoli, as described by Sabry et al. (2009, 2013) and Brandão et al. (2013). These authors detected changes in oyster tissues and organs infected by Perkinsus sp. in addition to phagocytosed trophozoites. In this study, no such changes were observed, possibly because of the lightness of the infection, but further studies are needed to better understand the effects of this pathogen on the host.

The results of the three detection methods employed in the present study (RFTM assay, histology and PCR) unequivocally confirm the occurrence of Perkinsus infecting native populations of $C$. rhizophorae in three estuaries in Northeastern Brazil. This is the first report of Perkinsus from coastal regions in northern South America. Although no Perkinsus-related mortality has been reported for this region, health surveillance of oyster populations in Northeast Brazil is advisable, especially when the identity of the species remains uncertain.

\section{Acknowledgements}

The authors would like to thank CAPES (Improvement Coordination of Personnel of Superior Level) for the doctoral scholarship awarded to Maximiano P. Dantas
Neto. This research was funded by the CAPES Marine Sciences Program.

\section{References}

ALMEIDA, M.F., BERTHE, F., THEBAULT, A. and DINIS, M.T., 1999. Whole clam culture as a quantitative diagnostic procedure of Perkinsus atlanticus (Apicomplexa, Perkinsea) in clams Ruditapes decussatus. Aquaculture (Amsterdam, Netherlands), vol. 177, no. 1-4, pp. 325-332. http://dx.doi.org/10.1016/S00448486(99)00095-2.

AZEVEDO, C., 1989. Fine structure of Perkinsus atlanticus n. sp. (Apicomplexa, Perkinsea) parasite of the clam Ruditapes decussatus from Portugal. The Journal of Parasitology, vol. 75, no. 4, pp. 627-635. http://dx.doi.org/10.2307/3282915. PMid:2760774.

BLACKBOURN, J., BOWER, S.M. and MEYER, G.R., 1998. Perkinsus qugwadi sp. nov. (incertae sedis), a pathogenic protozoan parasite of Japanese scallops, Patinopecten yessoensis, cultured in British Columbia, Canada. Canadian Journal of Zoology, vol. 76, no. 5, pp. 942-953. http://dx.doi.org/10.1139/z98-015.

BRANDÃO, R.P., BOEHS, G., SABRY, R.C., CEUTA, L.O., LUZ, M.S.A., QUEIROGA, F.R. and SILVA, P.M., 2013. Perkinsus sp. infecting oyster Crassostrea rhizophorae (Guilding, 1828) on the coast of Bahia, Brazil. Journal of Invertebrate Pathology, vol. 112, no. 2, pp. 138-141. http://dx.doi.org/10.1016/j.jip.2012.11.003. PMid:23201453.

BURRESON, E.M. and CALVO, L.M.R., 1996. Epizootiology of Perkinsus marinus disease of oysters in Chesapeake Bay, with emphasis on data since 1985. Journal of Shellfish Research, vol. 15 , pp. 17-34.

BURRESON, E.M., 2008. Misuse of PCR assay for diagnosis of mollusk protistan infections. Diseases of Aquatic Organisms, vol. 80, no. 1, pp. 81-83. http://dx.doi.org/10.3354/dao01925. PMid:18714688.

BURRESON, E.M., REECE, K.S. and DUNGAN, C.F., 2005. Molecular, morphological, and experimental evidence support the synonymy of Perkinsus chesapeaki and Perkinsus andrewsi. The Journal of Eukaryotic Microbiology, vol. 52, no. 3, pp. 258270. http://dx.doi.org/10.1111/j.1550-7408.2005.05-00035.x. PMid:15927003.

BUSH, A.O., LAFFERTY, A.D., LOTZ, J.M. and SHOSTAK, A.W., 1997. Parasitalogy meets ecology on its own terms: Margoli et al. revisited. The Journal of Parasitology, vol. 83, no. 4, pp. 575-583. http://dx.doi.org/10.2307/3284227. PMid:9267395.

CASAS, S.M., VILLALBA, A. and REECE, K.S., 2002. Study of perkinsosis in the carpet shell clam Tapes decussatus in Galicia (NW Spain). I. Identification of the aetiological agent and in vitro modulation of zoosporulation by temperature and salinity. Diseases of Aquatic Organisms, vol. 50, no. 1, pp. 51-65. http:// dx.doi.org/10.3354/dao050051. PMid:12152905.

CHOI, K.S. and PARK, K.I., 2010. Review on the protozoan parasite Perkinsus olseni (Lester and Davis 1981) infection in Asian waters. Coastal Environmental and Ecosystem Issues of the East China Sea, pp. 269-281.

ELANDALOUSSI, L.M., CARRASCO, N., ROQUE, A., ANDREE, K. and FURONES, M.D., 2009. First record of Perkinsus olseni, a protozoan parasite infecting the commercial clam Ruditapes decussatus in Spanish Mediterranean waters. Journal of Invertebrate Pathology, vol. 100, no. 1, pp. 50-53. http://dx.doi.org/10.1016/j.jip.2008.09.004. PMid:18823999. 
HOWARD, D.W., LEWIS, E.J., KELLER, B.J. and SMITH, C.S., 2004. Histological Techniques for Marine Bivalve Mollusks and Crustaceans. Massachusetts: Oxford. 218 p. NOAA Technical Memorandum.

LESTER, R.J.G. and DAVIS, G.H.G., 1981. A new Perkinsus species (Apicomplexa, Perkinsea) from the abalone Haliotis ruber. Journal of Invertebrate Pathology, vol. 37, no. 2, pp. 181-187. http://dx.doi.org/10.1016/0022-2011(81)90073-2.

MACKIN, J.G., OWEN, H.M. and COLLIER, A., 1950. Preliminary note on the occurrence of a new protistan parasite, Dermocystidium marinum $\mathrm{n}$. sp., in Crassostrea virginica (Gmelin). Science, vol. 111, no. 2883, pp. 328-329. http://dx.doi.org/10.1126/ science.111.2883.328. PMid:17791737.

OFFICE INTERNATIONAL DES EPIZOOTIES - OIE. WORLD ORGANISATION FOR ANIMAL HEALTH, 2012. Manual of diagnostic test for aquatic animals. Paris: OIE.

PENNA, M.S., KHAN, M. and FRENCH, R.A., 2001. Development of a multiplex PCR for the detection of Haplosporidium nelsoni, Haplosporidium costale and Perkinsus marinus in the eastern oyster Crassostrea virginica, Gmelin, 1971. Molecular and Cellular Probes, vol. 15, no. 6, pp. 385-390. http://dx.doi.org/10.1006/ mcpr.2001.0386. PMid:11851382.

RAY, S.M., 1954. Biological studies of Dermocystidium marinum, a fungus parasite of oysters. Houston: Rice Institute, $120 \mathrm{p}$. Doctoral Thesis in Natural Sciences.

RAY, S.M., 1966. A review of the culture method for detecting Dermocystidium marinum, with suggested modifications and precautions. Proceedings of the National Shellfisheries Association, vol. 54, pp. 55-69.

REECE, K.S., DUNGAN, C.F. and BURRESON, E.M., 2008. Molecular epizootiology of Perkinsus marinus and P. chesapeaki infections among wild oysters and clams in Chesapeake Bay, USA.
Diseases of Aquatic Organisms, vol. 82, no. 3, pp. 237-248. http:// dx.doi.org/10.3354/dao01997. PMid:19244976.

SABRY, R.C., GESTEIRA, T.C.V., MAGALHÃES, A.R.M., BARRACCO, M.A., GUERTLER, C., FERREIRA, L.P., VIANNA, R.T. and SILVA, P.M., 2013. Parasitological survey of mangrove oyster, Crassostrea rhizophorae, in the Pacoti River Estuary, Ceará State, Brazil. Journal of Invertebrate Pathology, vol. 112, no. 1, pp. 24-32. http://dx.doi.org/10.1016/j.jip.2012.10.004. PMid:23147104.

SABRY, R.C., ROSA, R.D., MAGALHÃES, A.R., BARRACCO, A.M., GESTEIRA, T.C. and SILVA, P.M., 2009. First report of Perkinsus sp. infecting mangrove oysters Crassostrea rhizophorae from the Brazilian coast. Diseases of Aquatic Organisms, vol. 88, no. 1, pp. 13-23. http://dx.doi.org/10.3354/dao02136. PMid:20183961.

SHAW, B.L. and BATTLE, H.I., 1957. The gross and microscopic anatomy of the digestive tract of the oyster Crassostrea virginica (Gmelin). Canadian Journal of Zoology, vol. 35, no. 3, pp. 325347. http://dx.doi.org/10.1139/z57-026.

SHEPPARD, B.J. and PHILLIPS, A.C., 2008. Perkinsus olseni detected in Vietnamese aquacultured reef clams Tridacna crocea imported to the USA, following a mortality event. Diseases of Aquatic Organisms. vol. 79, no. 3, pp. 229-235.

SILVA, P.M., VIANNA, R.T., GUERTLER, C., FERREIRA, L.P., SANTANA, L.N., FERNÁNDEZ-BOO, S., RAMILO, A., CAO, A. and VILLALBA, A., 2013. First report of the protozoan parasite Perkinsus marinus in South America infecting mangrove oysters Crassostrea rhizophorae from the Paraíba River (NE, Brazil). Journal of Invertebrate Pathology, vol. 113, no. 1, pp. 96-103. http://dx.doi.org/10.1016/j.jip.2013.02.002. PMid:23439264.

VILLALBA, A., REECE, K.S., ORDÁS, M.C., CASAS, S.M. and FIGUERAS, A., 2004. Perkinsosis in mollusks: a review. Aquatic Living Resources, vol. 17, no. 4, pp. 411-432. http:// dx.doi.org/10.1051/alr:2004050. 